\title{
The Effects of Bridge Abutments on the Benthic Macroinvertebrate Community
}

\author{
Zhengda Yu ${ }^{1}$, Hui Wang1, Renqing Wang1, 2, 3, Tongli He², Qingqing Cao', \\ Yutao Wang', Jian Liu ${ }^{1 *}$ \\ ${ }^{1}$ Institute of Environmental Research, Shandong University, Jinan 250100, China \\ ${ }^{2}$ School of Life Sciences, Shandong University, Jinan 250100, China \\ ${ }^{3}$ Shandong Provincial Engineering and Technology Research Center for Vegetation Ecology, Shandong University, \\ Jinan 250100, China
}

Received: 28 December 2015

Accepted: 20 February 2016

\begin{abstract}
A river ecosystem is a treasure that is home to a wide variety of wetland species. The construction of bridges might have a deep impact on diversity of such an ecosystem. The ecological consequence of bridge abutments was studied by monitoring the benthic macroinvertebrate community at six main bridges on the Tuhai and Majia rivers in eastern China. We collected samples of macroinvertebrates from upstream to downstream during the summer hight-water period, and we monitored water quality at each site. The macroinvertebrate community of under-bridge sites was significantly correlated with that of reference sites in abundance, biomass, and richness. The benthic macroinvertebrate communities were not significantly different between under-bridge sites and reference sites in terms of abundance and biomass, while they were significantly different in terms of richness and the Shannon-Wiener index. This pattern outlined a major impact of bridge abutments on benthic macroinvertebrate communities for the first time, indicating the importance of habitat restoration after river construction was finished. Suitable measures should be taken to minimize the impact of bridge abutments.
\end{abstract}

Keywords: alluvial bank, benthic macroinvertebrate, bridge abutment, river ecosystem, sediment deposition

\section{Introduction}

Anaquatic ecosystem can be impacted and fragmentized by a variety of stressors, including excess input of nutrients, geomorphological alterations, land use changes, hydrological stress, invasive species, and pathogens [14]. Fine-grained sediment has long been recognized as a major pollutant source that causes degradation of surface water bodies $[5,6]$. Excessive transport of sediment-

*e-mail: ecology@sdu.edu.cn bound nutrients to surface waters causes eutrophication of streams, rivers, and lakes, decreasing their recreational value. These fluvial sediments are important not only because of the massive amounts of chemicals and nutrients delivered with the sediments, but also the morphological changes [7-11].

Studies of sediment flux, its dispersal pattern, and geomorphological impact have also increasingly received attention [12-15]. Intensive studies about the impacts of hydraulic engineering have been conducted, i.e., the effects of the Three Gorges Reservoir on the macroinvertebrate community has been carried out over the past several 
years $[4,16]$. Different processes that could contribute to sedimentation problems include erosion of uplands and channel bank collapse/erosion [17]. The linkage among upland erosion, sediment mobilization, and downstream sediment yield is complex due to uncertainties associated with sediment retention and storage at intermediate locations such as floodplains, streambeds, and foots of hill slopes [18]. The increase in deposition and storage of fine sediment on stream beds could result in the degradation of the physical, chemical, and biological status of watersheds $[19,20]$. Fine sediment deposition on streambeds can cause damage to salmonid spawning beds by reducing the oxygen supply to hatching ova and invertebrates [21]. Only a few studies have focus on impacts of fine sediment deposition on macroinvertebrates [22].

Bridge abutments, the inevitable artificial structures across rivers, are places that easily collect deposits. During the low-water period, the sluices are shut down to meet the need of irrigation water demand. The sediments easily deposit around the abutments because of the low flow velocity. Water scour leads the migration of the substrate from abutments to river bed and the bottom materials deposit along the river bed. The river bank becomes alluvial and bare, which is different from the normal one. However, until now, dredging has been the most popular way to solve this problem in China. As a consequence, biodiversity decline is one of the greatest ecological problems threatening aquatic ecosystems [23], while no research has been done about the effects of bridge abutment construction.

The most seriously polluted rivers, the Tuhai and Majia, are located in the most densely populated province of Shandong, China. The population density is more than 550 per $\mathrm{km}^{2}$ and the crops and residential land occupy more than $95 \%$ [24]. Freshwater is a finite resource which is irreplaceable in life, development, and environment. The Tuhai and Majia mainly provide irrigation for the farmland. However, they are contaminated and their water is not fit for it intended use. Previous studies in this region have been carried out by the chemical field regarding heavy metal risk assessment [25], polycyclic aromatic hydrocarbons ecological risk [26], and organic carbon distribution [27], as well as economic studies [24]. No study has been carried out about the effects of bridge abutment construction on the macroinvertebrate communities in rivers.

In China there is an increasing trend to use macroinvertebrate communities in rivers, lakes, and wetlands as indicators of environmental quality [4, 16, 28-31]. Biomonitoring has the advantage that it can detect cumulative physical, chemical, and biological impacts of adverse activities on an aquatic system. Aquatic macroinvertebrates are often preferred for biomonitoring for the following three reasons: firstly, they are not very mobile and therefore they are representative of the area from which they are collected; secondly, they have relatively short life cycles and therefore can reflect environmental changes quickly through changes in their community composition; and thirdly they respond to pollutants in both the water column and sediments [32]. As a monitoring indicator of aquatic ecosystem health, how do macroinvertebrate perform in such seriously polluted rivers?

The aim of this study in the Tuhai and Majia rivers is to explore the impacts of two sorts of anthropogenic activities: water pollution and bridge abutments on the macroinvertebrate community. And to exam whether macroinvertebrates could be an indicator in severely contaminated water or be used in other ways to evaluate river health.

\section{Material and Methods}

\section{Study Area Sites}

The study area, the Tuhai Majia Basin, lies in northern China from $35^{\circ} 41^{\prime} \mathrm{N}$ to $38^{\circ} 08^{\prime} \mathrm{N}$ and from $114^{\circ} 51^{\prime} \mathrm{E}$ to $118^{\circ} 58^{\prime} \mathrm{E}$ (Fig. 1). It is an alluvial plain of the Yellow River with an area of $30,945 \mathrm{~km}^{2}$, including an agricultural

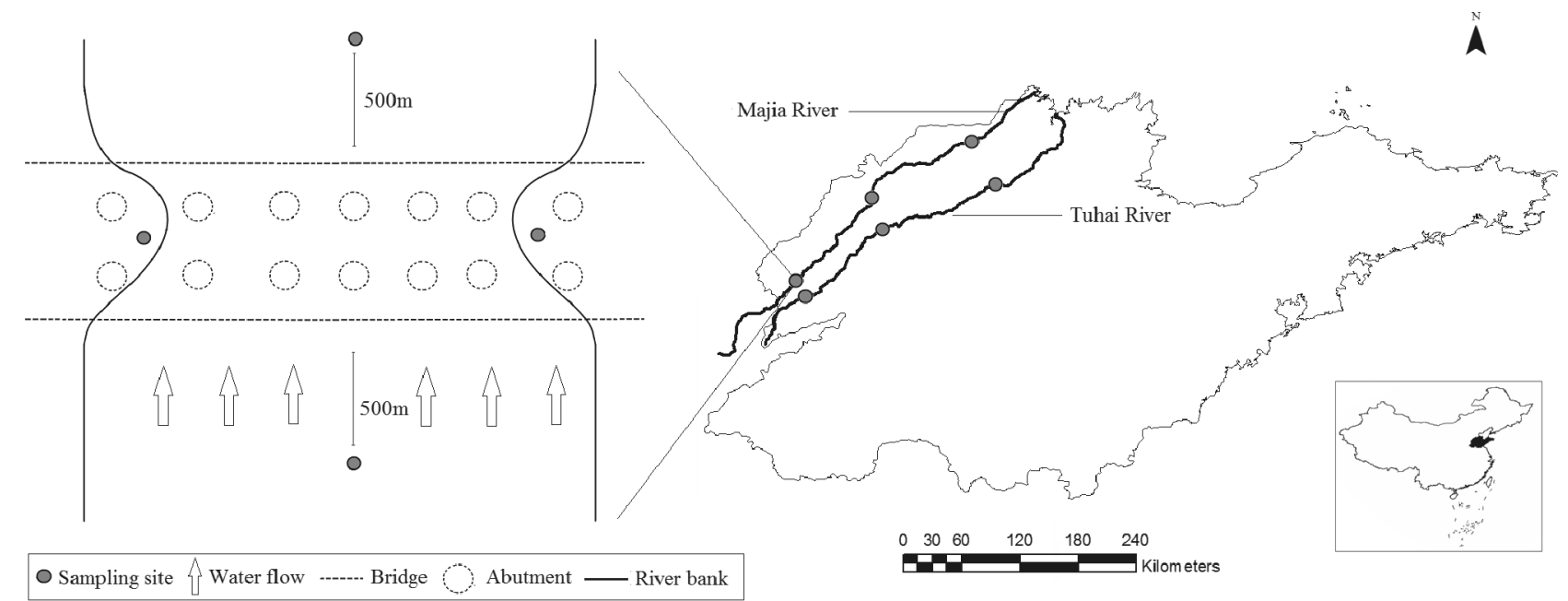

Fig. 1. Location of Tuhai River, Majia River and the sampling sites. 
Table 1. Biological and chemical characteristics in the Tuhai and Majia rivers.

\begin{tabular}{|c|c|c|c|c|c|c|}
\hline \multirow{2}{*}{ Location } & \multicolumn{3}{|c|}{ Tuhai River } & \multicolumn{3}{c|}{ Majia River } \\
\cline { 2 - 7 } & Upstream & Mid-stream & Down Stream & Upstream & Mid-stream & Down Stream \\
\hline Abundance (ind) & 416 & 2744 & 39 & 371 & 109 & 92 \\
\hline Richness & 8 & 8 & 6 & 6 & 3 & 6 \\
\hline Biomass (g) & 69.37 & 621.51 & 61.04 & 55.5 & 55.06 & 17.33 \\
\hline Shannon-Wiener index & 1.43 & 0.33 & 1.73 & 1.76 & 1.05 & 2.11 \\
\hline COD (mg L-1) & 26.66 & 27.18 & 22.70 & 36.00 & 30.20 & 29.76 \\
\hline $\mathrm{NH}_{4}-{\mathrm{N}\left(\mathrm{mg} \mathrm{L}^{-1}\right)}^{\text {Dissolved oxygen (mg L-1) }}$ & 0.46 & 1.16 & 0.70 & 0.78 & 1.02 & 1.12 \\
\hline
\end{tabular}

region with great demand for water resources. However, the basin stands in an area of China with a serious water shortage [33]. For this paper we investigated 24 sites distributed along the rivers. We also investigated potential physicochemical and anthropogenic stressors in the rivers.

\section{Macroinvertebrate Sampling and Community Analysis}

Macroinvertebrate communities were sampled from June to September in 2013, following a multi-habitat scheme (Fig. 1, four sampling at each site: two sites sampled at a silted riverbed under the bridge; two sites sampled along the riverbank $500 \mathrm{~m}$ upstream and downstream from the bridge as reference samples) upstream, mid-stream, and downstream of the rivers. A $0.3 \mathrm{~m} \times 0.3 \mathrm{~m}$ surber net $(0.25 \mathrm{~mm})$ was the main sampler. The surber net was put on the shallow bottom of the river and then the substratum was agitated by hand to collect benthic macroinvertebrates into the net. Other sample methods were also used to make sure that most macroinvertebrate individuals were collected in sample quadrats. The collected individuals at each site were put into plastic bottles filled with $75 \%$ ethanol to preserve the samples. Taxa were identified at the family level in a laboratory. Then a list of taxa, abundance, and biomass was made from the 36 sites. Based on the list, the following indices were calculated for each site: 1) abundance, 2) richness, 3) biomass, and 4) ShannonWiener index.

\section{Chemical Parameters}

A suite of chemical parameters, including dissolved oxygen $\left(\mathrm{mg} \mathrm{L}^{-1}\right), \mathrm{NH}_{4}-\mathrm{N}\left(\mathrm{mg} \mathrm{L}^{-1}\right)$, and chemical oxygen demand $\left(\mathrm{mg} \mathrm{L}^{-1}\right)$ were analyzed monthly from the surface water of the research sites at the monitoring station. Average data from May to September was used for analysis.

\section{Statistical Analyses}

Between-site differences in concentration of $\mathrm{NH}_{4}-\mathrm{N}$, chemical oxygen demand, dissolved oxygen, abundance of macroinvertebrates, richness, biomass, and ShannonWiener index (Eq. 1) were tested using Pearson correlation analysis [34]. For each biological variable, comparisons between reference sites and under-bridge sites were performed using paired-samples T test. Statistical analyses were performed with SPSS 18.0. Maximum type-I error rates were set at $\alpha=0.05$.

$$
\mathrm{H}^{\prime}=-\sum_{i=1}^{R} p_{i} \log _{2} p_{i}
$$

...where $p_{i}$ is the proportion of individuals belonging to the $i$ th species in the related dataset.

\section{Results}

The main values of water quality $\left(\mathrm{NH}_{4}-\mathrm{N}\right.$, chemical oxygen demand, and dissolved oxygen) and macroinvertebrate community (abundance, richness, biomass, Shannon-Wiener index) for each of the two rivers and three sampling sites (upstream, mid-stream, and downstream) are reported in Table 1.

The mean values of dissolved oxygen ranged from $4.82 \mathrm{mg} \mathrm{L}^{-1}$ downstream of the Tuhai to $7.51 \mathrm{mg} \mathrm{L}^{-1}$ in the headwaters of the Majia (Table 1). Table 2 presents Spearman's correlation coefficients between chemical and biological metrics. Only some macroinvertebrate metrics such as abundance and biomass were significantly correlated to dissolved oxygen (Table 2). Conversely, neither Chemical oxygen demand nor $\mathrm{NH}_{4}-\mathrm{N}$ was correlated to any biological characteristics (Table 2).

In 2013 a total of 3,748 macroinvertebrate individuals belonging to 16 species were collected from the studied sites. The total number of individuals present at each site ranged from 39 to 2,744 (Table 3). There were eleven and nine species in the Tuhai and Majia, respectively. We reviewed how many taxa were represented in each site. The mean Shannon-Wiener index values at each site were $0.84 \pm 0.38$ in the Tuhai and - a little higher $-1.15 \pm 0.48$ in the Majia. Richness at most reference sites was higher than that at under-bridge sites as well as the ShannonWiener index (Fig. 2). The richness at reference sites 3 and 4 was comparatively higher than average, but H' was 
Table 2. Pearson correlation analysis between biological metric chemical parameters in the Tuhai and Majia rivers.

\begin{tabular}{|c|c|c|c|}
\hline Metrics & Chemical parameters & $\mathrm{R}$ & p-value \\
\hline \multirow{3}{*}{ Abundance } & $\begin{array}{c}\text { Chemical oxygen } \\
\text { demand }\end{array}$ & -0.156 & 0.768 \\
\hline & $\mathrm{NH}_{4}-\mathrm{N}$ & 0.153 & 0.773 \\
\hline & Dissolved oxygen & -0.882 & 0.020 \\
\hline \multirow{3}{*}{ Richness } & $\begin{array}{c}\text { Chemical oxygen } \\
\text { demand }\end{array}$ & 0.028 & 0.958 \\
\hline & $\mathrm{NH}_{4}-\mathrm{N}$ & 0.087 & 0.870 \\
\hline & Dissolved oxygen & -0.323 & 0.532 \\
\hline \multirow{3}{*}{ Biomass } & $\begin{array}{c}\text { Chemical oxygen } \\
\text { demand }\end{array}$ & -0.089 & 0.867 \\
\hline & $\mathrm{NH}_{4}-\mathrm{N}$ & 0.661 & 0.153 \\
\hline & Dissolved oxygen & -0.957 & 0.003 \\
\hline \multirow{3}{*}{$\begin{array}{c}\text { Shannon- } \\
\text { Wiener index }\end{array}$} & $\begin{array}{c}\text { Chemical oxygen } \\
\text { demand }\end{array}$ & 0.365 & 0.477 \\
\hline & $\mathrm{NH}_{4}-\mathrm{N}$ & 0.493 & 0.320 \\
\hline & Dissolved oxygen & 0.327 & 0.527 \\
\hline
\end{tabular}

the lowest among all sampling sites. H' of UBS at sites 5 and 7 was a little higher than that of RS, while richness assumed the opposite trend, illustrating that the bridge affected richness more than $\mathrm{H}^{\prime}$ (Fig. 2). a)

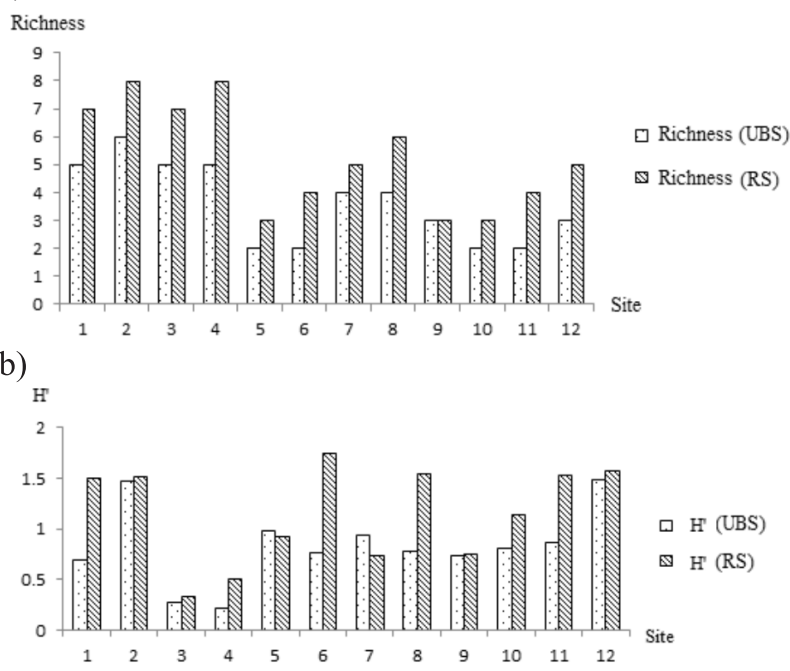

Fig. 2. Richness a) and Shannon-Wiener index b) in under-bridge site (UBS) and reference site (RS).

We conducted a sequence of analysis among biological characteristics. There were no significant differences between under-bridge sites and reference sites in abundance $(p=0.487)$ and biomass $(p=0.485)$, while richness $(p<0.001)$ and Shannon-Wiener index $(p=0.019)$ both showed significant difference (Table 4). Pearson correlation drew very significantly between under-bridge sites and reference sites (abundance: $R=0.961, p<0.001$;

Table 3. Numbers, names, and locations of macroinvertebrates.

\begin{tabular}{|c|c|c|c|c|c|c|}
\hline Species & TUS & TMS & TDS & MUS & MMS & MDS \\
\hline Limnodrilus claparedianus & & 2 & & & & \\
\hline Branchiura sowerbyi & 37 & 13 & & & & 3 \\
\hline Chironomidae sp.1 & 18 & 20 & & & & \\
\hline Chironomidae sp.2 & & & & 22 & & 7 \\
\hline Cipangopaludina catnayensis & 308 & 34 & 19 & 302 & 81 & 58 \\
\hline Corixa substriata & 3 & & & & 9 & \\
\hline Glossiphonia sp. & & 3 & 3 & & & \\
\hline Lamprotula sp.1 & & & 1 & & & \\
\hline Lamprotula sp.2 & & 24 & & & & \\
\hline Limnodrilus hoffmeisteri & 5 & & & 3 & & 1 \\
\hline Odonata $s p$ & & & & 10 & & \\
\hline Palaemon sp. & & & 1 & & & \\
\hline Planorbidae sp. & 15 & & & & & \\
\hline Radix swinhoei & 2 & 9 & 1 & 4 & & 18 \\
\hline Semisulcospira cancellata & & & & & 19 & \\
\hline Tubifex sinicus & 28 & 2639 & 14 & 30 & & 5 \\
\hline Total & 416 & 2744 & 39 & 371 & 109 & 92 \\
\hline
\end{tabular}


Table 4. Pearson correlation analysis and paired-samples T test between reference sites (RS) and under-bridge sites (UBS) in abundance, biomass, richness, and Shannon-Wiener index.

\begin{tabular}{|c|c|c|c|c|}
\hline \multirow{2}{*}{ Metrics } & \multicolumn{3}{|c|}{ Correlation } & Paired-samples T test \\
\cline { 2 - 5 } & $\mathrm{N}$ & $\mathrm{R}$ & $\mathrm{Sig}$. & Sig. \\
\hline Abundance & 12 & 0.961 & $<0.001$ & 0.487 \\
\hline Biomass & 12 & 0.931 & $<0.001$ & 0.485 \\
\hline Richness & 12 & 0.930 & $<0.001$ & $<0.001$ \\
\hline Shannon-Wiener index & 12 & 0.603 & 0.038 & 0.019 \\
\hline
\end{tabular}

biomass $\mathrm{R}=0.931 \mathrm{p}<0.001$; richness $\mathrm{R}=0.930, \mathrm{p}<0.001$ - Table 4).

\section{Discussion}

Aquatic macroinvertebrates are often preferred for bio-monitoring because they can detect cumulative impacts of an aquatic system [35-37]. In the present study, no measured chemical parameters were significantly correlated to biological variables except dissolved oxygen. This might be because that tolerant species dominates the study area as a result of impacts of agriculture and industry. $\mathrm{NH}_{4}-\mathrm{N}$ and chemical oxygen demand were the main water quality measurements in China. In addition to other frequent human activities, agricultural land use occupied a great proportion in the catchment area of the two rivers, leading to the degradation of riparian habitats and loss of biodiversity. Thus macroinvertebrates cannot be suitable indicators for monitoring such a polluted river ecosystem.

In both rivers, the macroinvertebrate communities were dominated by Oligochaeta, Diptera, and mollusks, which belong to the tolerant taxa that could somewhat endure water pollution. No sensitive taxa such as Ephemeroptera, Plecoptera, and Trichoptera were found in our study. Furthermore, compared to the upstream Hai River basin with good water quality, the total number of families $(n=16)$ observed in the present study was much lower than that in the headwaters $(n=90)$ [38]. In the

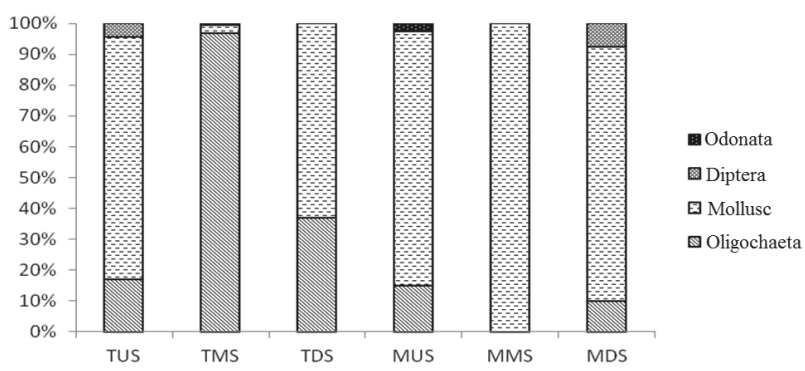

Fig. 3. Relative abundance of the main taxonomic groups of macroinvertebrates at each sampling site in 2013 (TUS = Tuhai upstream, TMS = Tuhai middle stream, TDS = Tuhai downstream, MUS = Majia upstream, MMS = Majia middle stream, MDS = Majia downstream). upstream Tuhai and Majia rivers, (Fig. 3 TUS and MUS), the macroinvertebrate community was dominated by mollusks $(78.7 \%, 82 \%)$ followed by Oligochaeta $(16.9 \%$, $14.8 \%$ ), which were similar to downstream figures (TDS and MDS). Combined with chemical variables, the results indicate that the Tuhai and Majia are seriously polluted along their entire length.

In Shandong, with a population of 100 million, bridges are essential for transportation. There is on average one bridge every three kilometers along the Tuhai $(436.35 \mathrm{~km}$, 157 bridges in total) and Majia (521 km, 180 bridges in total). The effects caused by bridges on macroinvertebrate communities cannot be ignored, and bridge construction will never stop. What we are generally concerned about is the stability of bridges navigation safety during flooding. Not only the substrate but also the river bank is changed by turbulent flow and deposition. The investigation results indicated that the riverbed under the bridge is consistently added to by silt deposits. Insect species such as Ephemeroptera, Plecoptera, and Trichoptera were the most vulnerable to adverse changes of the river bank. Few

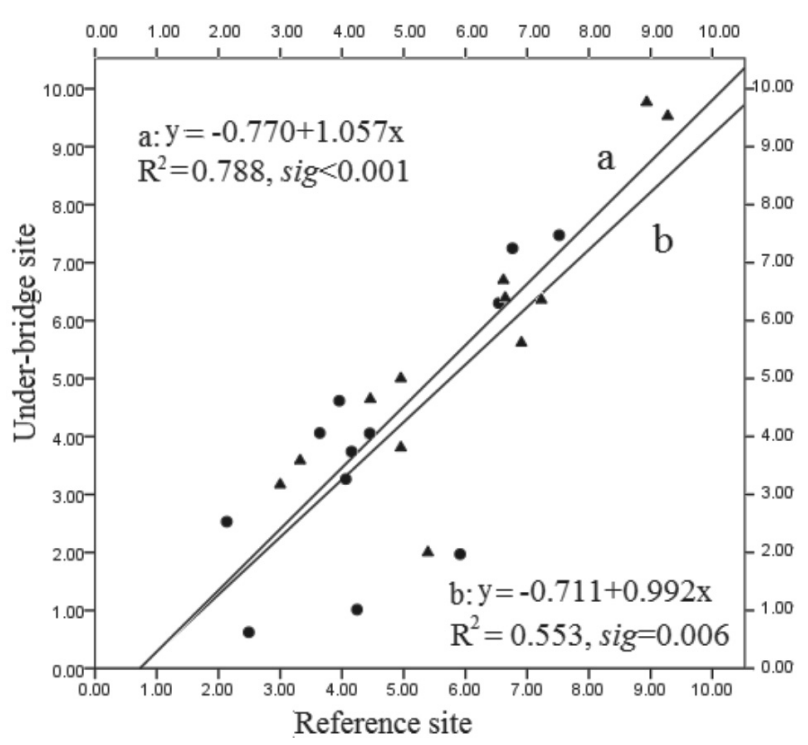

Fig. 4. Abundance and biomass correlation between under-bridge sites and reference sites. a $\boldsymbol{\Delta}$ : correlation of log-transformed abundance between under-bridge sites and reference sites; b•: correlation of biomass between under-bridge sites and reference sites. 
insect species can reproduce in such a degraded ecosystem without vegetation except Chironomidae and Diptera (Fig. 3).

The difference of richness between the normal sites and the under-bridge sites is significant mainly because of the absence of insects at under-bridge sites. Conversely, the relationship of abundance and biomass between under-bridge sites and reference sites demonstrated that the tolerant species Oligochaetes (contributing to abundance) and mollusks (contributing to biomass) were barely affected by such habitat degradation. Moreover, correlation of log-transformed abundance and biomass between under-bridge sites and reference sites had nearly the same slope and intercept (Fig. 4).

\section{Conclusions}

River bank ecosystem degradation on account of sediment deposition and scouring around bridge abutments evidently affects the macroinvertebrate community structure and diversity. It is not suitable to use only macroinvertebrate diversity as an indicator of river ecosystem health, but sensitive species should be given more attention - especially in a polluted river system.

\section{Acknowledgments}

This study was financially supported by the National Water Special Project (No. 2012ZX07203-004), the National Natural Science Foundation of China (No. 31200426), and the Fundamental Research Funds of Shandong University (No. 2015JC023).

\section{References}

1. NGUYEN T.G.T., BOETS P., LOCK K., AMBARITA M.N.D., FORIO M.A.E., SASHA P., DOMINGUEZGRANDA L.E., HOANG T.H.T., EVERAERT G., GOETHALS P.L.M. Habitat suitability of the invasive water hyacinth and its relation to water quality and macrovinvertebrate diversity in a tropical reservoir. Limnologica. 52, 67, 2015

2. BRAUKMANN U., BÖHME D. Salt pollution of the middle and lower sections of the river Werra (Gemany) and its impact on benthic macroinvertebrates. Limnologica. 41, 113, 2011.

3. MÁRQUEZ J.A., CIBILS L., PRINCIPE R.E., ALBARINO R.J. Stream macroinvertebrate communities change with grassland afforestation in central Argentina. Limnologica. 53, 17, 2015.

4. LIB., CAIQ.H.,ZHANG M., SHAO M.L. Macroinvertebrate community succession in the Three-Gorges Reservoir ten years after impoundment. Quatern. Int. 380-381, 247, 2015.

5. WALLING D.E., FANG D. Recent trends in the suspended sediment loads of the world's rivers. Global Planet Change. 39, 111, 2003.

6. DEVEREUX O.H., PRESTEGAARD K.L., NEEDELMAN B.A., GELLIS A.C. Suspended-sediment sources in an urban watershed, Northeast Branch Anacostia River, Maryland. Hydrol. Process. 24, 1391, 2010.

7. MEADE R. River-Sediment Inputs to Major Deltas. Springer Netherlands. Coastal Systems and Continental Margins, 63, 1996.

8. SYVITSKI J.P.M., MILLIMAN J.D. Geology, Geography, and Humans Battle for Dominance over the Delivery of Fluvial Sediment to the Coastal Ocean. J. Geol. 115, 1, 2007.

9. FAN H., HUANG H. Response of coastal marine ecoenvironment to river fluxes into the sea: A case study of the Huanghe (Yellow) River mouth and adjacent waters. Mar. Environ. Res. 65, 378, 2008.

10. WANG H., BI N., SAITO Y., WANG Y., SUN X., ZHANG J., YANG Z. Recent changes in sediment delivery by the Huanghe (Yellow River) to the sea: Causes and environmental implications in its estuary. J. Hydro. 391, 302, 2010.

11. COHEN S., KETTNER A.J., SYVITSKI J.P.M. Global suspended sediment and water discharge dynamics between 1960 and 2010: Continental trends and intra-basin sensitivity. Global Planet Change. 115, 44, 2014

12. MEYBECK M., VÖRÖSMARTY C. Fluvial filtering of land-to-ocean fluxes: from natural Holocene variations to Anthropocene. C R Geoscience 337, 107, 2005.

13. NILSSON C., REIDY C.A., DYNESIUS M., REVENGA C. Fragmentation and Flow Regulation of the World's Large River Systems. Science. 308, 405, 2005.

14. SYVITSKI J.P.M., VÖRÖSMARTY C.J., KETTNER A.J., GREEN P. Impact of Humans on the Flux of Terrestrial Sediment to the Global Coastal Ocean. Science. 308, 376, 2005.

15. HSU H.H., LIU C.S., YU H.S., CHANG J.H., CHEN S.C. Sediment dispersal and accumulation in tectonic accommodation across the Gaoping Slope, offshore Southwestern Taiwan. J Asian Earth Sci, 69, 26, 2013.

16. PAN B.Z., WANG H.Z., BAN X., YIN X.A. An exploratory analysis of ecological water requirements of macroinvertebrates in the Wuhan branch of the Yangtze River. Quaternary Int, 380-381, 256, 2015.

17. WILSON C.G., KUHNLE R.A., BOSCH D.D., STEINER J.L., STARKS P.J., TOMER M.D., WILSON G.V. Quantifying relative contributions from sediment sources in Conservation Effects Assessment Project watersheds. J. Soil Water Conserv. 63, 523, 2008.

18. WALLING D.E., COLLINS A.L., STROUD R.W. Tracing suspended sediment and particulate phosphorus sources in catchments. J. Hydrol. 350, 274-, 2008.

19. WOOD P.J., ARMITAGE, P.D. Biological effects of fine sediment in the lotic environment. Environ. Manag. 21, 203, 1997.

20. COLLINS A.L., WALLING D.E. Fine-grained bed sediment storage within the main channel systems of the Frome and Piddle catchments, Dorset, UK. Hydrol. Process. 21, 1448, 2007.

21. WALLING D.E., AMOS C.M. Source, storage and mobilisation of fine sediment in a chalk stream system. Hydrol. Process. 13, 323, 1999.

22. LAMBA J., THOMPSON A.M., KARTHIKEYAN, K.G., FITZPATRICK F.A. Sources of fine sediment stored in agricultural lowland streams, Midwest, USA. Geomorphology. 8505, 44, 2015.

23. BEKETOV M.A., KEFFORD B.J., SCHÄFER R.B., LIESS M. Pesticides reduce regional biodiversity of stream invertebrates. Proc. Natl. Acad. Sci. U.S.A. 110, 11039, 2013.

24. HUANG D.J., ZHUANG D.F., ZHU Y.Q., FU J.Y. An improved approach for modeling spatial distribution of 
water use profit - A case study in Tuhai Majia Basin, ChinaYaohuan. Ecol. Indic. 36, 94, 2014.

25. TANG W.Z., ZHAO Y., WANG C., SHAN B.Q., CUI J.G. Heavy metal contamination of overlying waters and bed sediments of Haihe Basin in China. Ecotox Environ Safe. 98, 317, 2013.

26. LIU F., LIU J., CHEN Q., WANG B., CAO Z. Pollution characteristics, ecological risk and sources of polycyclic aromatic hydrocarbons (PAHs) in surface sediment from Tuhai-Majia River system, China. 2012 Environmental Sciences. 13, 1301, 2012.

27. CAO Q.Q., WANG R.Q., LIU J. Composition and distribution of organic carbon in river sediments: a case study of two northern Chinese rivers. Pol.j.Environ. Stud. 24, 969, 2015.

28. CHEN Q.W., YANG Q.R., LI R.N., MA J.F. Spring microdistribution of macroinvertebrate in relation to hydroenvironmental factors in the Lijiang River, China. J HydroEnviron Res. 7, 103, 2013.

29. CHEN K., HUGHES R.M., XU S., ZHANG J., CAI D.S., WANG B.X. Evaluating performance of macroinvertebratebased adjusted and unadjusted multi-metric indices (MMI) using multi-season and multi-year samples. Ecol. Indic. 36, 142, 2014.

30. CHEN K., HUGHES R.M., WANG B.X. Effects of fixedcount size on macroinvertebrate richness, site separation, and bioassessment of Chinese monsoonal streams. Ecol. Indic. 53, 162, 2015.

31. LI F.Q., CAI Q.H., QU X.D., TANG T., WU N.C., FU X.C., DUAN S.G., JÄHNIG S.C. Characterizing macroinvertebrate communities across China: Large-scale implementation of a self-organizing map. Ecol. Indic. 23, 394, 2012.

32. REECE F.P., RICHARDSON S.J. Biomonitoring with the reference condition approach for the detection of aquatic ecosystems at risk. In: Darling, L.M. (Ed.), Proceedings of a Conference on the Biology and Management of Species and Habitats at Risk, Kamloops, British Columbia, 15-19 February 1999. British Columbia Ministry of Environment: Lands and Parks/University College of the Cariboo, Victoria, B.C./Kamloops, B.C., 549, 2000.

33. HUANG Y., WANG J., JIANG D., ZHOU Q. Regionalization of surface water shortage of China based on evapotranspiration. J. Hydrol. Eng. 40, 927, 2009.

34. SHANNON C.E., WEAVER W. The mathematical theory of communication. University of Illinois Press, 1949.

35. GUILPART A., ROUSSLE J., AUBIN J., CAQET T., MARLE M., BRIS H.L. The use of benthic invertebrate community and water quality analyses to assess ecological consequence of fish farm effluents in rivers. Ecol. Indic. 23, 356, 2012.

36. LEITNER P., HAUER C., OFENBÖCK T., PLETTERBAUER F., SCHMIDT-KLOIBER A., GRAF W. Fine sedment deposition affeces biodiversity and density of benthic macroinvertebrates: A case study in the freshwater pearl mussel river Waldaist (Upper Austria). Limnologica. 50, 54, 2015.

37. MEHARI A.K., WONDIE A., MINGIST M., VIJERBERG J. Spatial and seasonal variation in the macro-invertebrates and physic-chemical parameters of the Enfranz River, Lake Tana sub-basin (Ethiopia). Ecohydrology \& Hydrobiology. 14, 304, 2014.

38. LI J.T., LI J., ZHAN F.B., ZHONG J., XIAO S., ZHANG D.L., WANG W.M. Diversity of Benthic Macroinvertebrates in Luanhe River Basin in Summer. Chinese Agricultural Science Bulletin. 31, 40, 2015 [In Chinese]. 